\title{
New Methods in University Entrepreneurship Education: A Multidisciplinary Teams Approach
}

\author{
Francisco J. García-Rodríguez ${ }^{1}$, Esperanza Gil-Soto ${ }^{1}$, Inés Ruiz-Rosa ${ }^{2}$ \\ ${ }^{1}$ Department of Economics and Business Administration, University of La Laguna, \\ San Cristóbal de La Laguna, Spain \\ ${ }^{2}$ Department of Financial Economics and Accounting, University of La Laguna, San Cristóbal de La Laguna, Spain \\ Email: fgarciar@ull.es
}

Received September $6^{\text {th }}$, 2012; revised October $4^{\text {th }}$, 2012; accepted October $20^{\text {th }}, 2012$

\begin{abstract}
There is currently much debate about what methodological innovations are necessary for entrepreneurship education in universities in the new competitive context. The current work describes the methodology, process of implementation and main results from the evaluation of the first year of a project to test an innovative teaching methodology involving the elaboration of business plans by multidisciplinary teams of university students studying degrees in chemical engineering, industrial engineering, computer engineering, and business management in the University of La Laguna (Spain). The results suggest that the methodology has the potential to boost entrepreneurial spirit among the students, and that it is a model of learning that is closer to reality than more traditional methodologies.
\end{abstract}

Keywords: Entrepreneurship Education; Multidisciplinary Teams; Innovative Teaching Methodology; Business Plans; Higher Education

\section{The University Role in Entrepreneurship Education}

Since Myles Mace taught the first entrepreneurship course at Harvard Business School in 1947, the number of education programs designed to instill entrepreneurial spirit and ultimately boost new firm creation has continued to grow, leading one author to claim that "the younger generation of the 21st century is becoming the most entrepreneurial generation since the Industrial Revolution” (Kuratko, 2005: p. 578).

This proliferation of entrepreneurship education programs is a consequence of the positive effects that entrepreneurship has in terms of economic growth and job creation (Audretsch, 2003), as well as the recognition that entrepreneurship education has now reached full maturity (Katz, 2008) and is close to gaining full legitimacy (Kuratko, 2005) as a scientific and academic discipline. According to Kuratko (2005), the question is not whether entrepreneurship can be taught, but what should be taught and how it should be taught (Honig, 2004; Fiet, 2000).

However, despite this huge growth in entrepreneurship education, particularly in the universities, researchers have shown relatively little interest in identifying the benefits that students gain from participating in these programs (Peterman \& Kennedy, 2003; Athayde, 2009).

On the other hand, the profound changes affecting the economy, the technological revolution and the social and environmental crisis, among other aspects, are generating increasingly greater levels of uncertainty and even "unknowability". Thus educators need to profoundly rethink the methods and approaches they use in the University (Neck \& Greene, 2011; Béchard \& Grégoire, 2005; Fiet, 2000). In the same line, “entrepreneurship within a formal education structure requires a new approach based on action and practice” (Neck \& Greene, 2011: p. 68).

Educational institutions should adopt 21st century methods and tools to develop the appropriate learning environment for encouraging creativity (Zhou \& Luo, 2012), innovation and the ability to "think out of the box" to solve problems (World Economic Forum, 2009). Indeed, the weakest aspects of existing models of business planning education is that the process supports thinking "inside the box", which may serve to reduce rather than expand the range of activities and potential solutions pursued by nascent entrepreneurs (Honig, 2004).

The above is particularly important in the context of higher education in Europe, given the conclusions of a study from The Commission of The European Communities (2008) among 664 higher-education institutions:

- Less than half of university students have access to some type of initiative related to the development of entrepreneurial spirit

- European universities are trailing far behind US and Canadian universities in this area

- Very little cooperation takes place between institutions to exchange good practices

- Most institutions allocate less than $€ 50$ per student per year to promoting entrepreneurial spirit

- It is necessary to agree on a more inclusive definition of what is understood by entrepreneurial education.

These findings contrast with the situation in the US, symbolized by the paradigmatic case of the Massachusetts Institute of Technology (MIT). MIT's success seems to be due to its science and engineering resources, the quality of its research, its organizational mechanisms and policies in support of entrepreneurship (such as its Technology Licensing Office) and its culture, which strongly encourages entrepreneurship (O’Shea et al., 2007). This reflects the fact that "[t]he image of entrepreneurs as positive role models has never been as strong in Europe as in the US" (Commission of The European Communities, 2003: p. 5).

In this context, a group of professors at the University of $\mathrm{La}$ 
Laguna (Spain) conducted a project to test an innovative methodology for teaching entrepreneurship. The project involved the drawing up of business plans by multidisciplinary teams of students studying for degrees in chemical engineering, Industrial engineering, computer engineering and business management. In the current work, the authors present the methodology they followed and the main results from the evaluation of the impact of participating in the project among the students. They offer their main conclusions from the experiment and suggest possible improvements for the future.

\section{A Practical Initiative: Multidisciplinary Teams of University Students}

\section{Description of Project}

A group of professors at the University of La Laguna (Spain) who teach four courses from four different degree programs in business management and the engineering sciences carried out a project to test an innovative methodology for teaching entrepreneurship and inculcating entrepreneurial spirit among the students. The project involved setting up multidisciplinary teams of students to draw up business projects on the basis of an idea. The starting point for the project was the following ideas about the role and potential of entrepreneurship education in the University:

- Entrepreneurship education could offer a broad, integrative, pragmatic, and rational approach to business, avoiding the problem of the continued increasing fragmentation of business education into narrow specializations (Kuratko, 2005; Zeithaml \& Rice, 1987).

- On the other hand, teaching entrepreneurship requires a multidimensional and cross-disciplinary approach with an emphasis on dynamic processes (Fayolle, 2007). In this respect, Kuratko (2005: p. 584) notes the trend in "new interdisciplinary programs that use faculty teams to develop programs for the nonbusiness students”. For this, universities need to change their structures with regard to their entrepreneurship classes, because they only offer these classes to students from one or sometimes two disciplines (Fayolle, 2007).

According to the above considerations, the professors formed multidisciplinary teams consisting of two distinct sets of students: first, students studying one, and not more than one, of computer, chemical or industrial engineering; and second, business management students. The idea was that they work together to develop a business idea and draw up a business plan. The students coming from the scientific-technical areas would conceivably contribute a more technical and operational perspective to the project, while the business management students would offer the vision and conceptualization of the business, support in the market research, and above all the economicfinancial analysis. The business management students would be acting as "business consultants", advising the scientific-technical students in the development of the business plan.

The four professors teaching the courses involved participated in the project. Of the 217 students registered on the four courses, a little over half (109) were studying one of the engineering degrees and the rest were studying business management. A total of 12 interdisciplinary teams of students were established. The teams ranged in size from 11 to 20 members, with a mean of 16 .

After four months the results of the project were evaluated.
For this, the professors drew up a questionnaire to measure participating students' satisfaction with and evaluation of the project. The next section describes this evaluation process and the main results obtained.

\section{Methodology of Evaluation}

For the evaluation process a questionnaire was drawn up. The questionnaire had its basis, on the one hand, on the dimensions for assessing the quality of a project for testing an innovative teaching methodology for entrepreneurship, and on the other, on the attributes defining entrepreneurial activity according to the Annual Report of the GEM Spain project (De la Vega et al., 2009).

With regard to the quality of the project, and following Mauri, Coll and Onrubia (2007), the questionnaire considered four dimensions: implementation of the project; results of learning; fundamental elements of the innovative methodology; and degree of satisfaction. The next step involved establishing a set of indicators to define each dimension of the construct. These variables made up the questionnaire sent to the students participating in the project. Table 1 presents the items grouped into the four main dimensions.

The population object of study consisted of all students officially registered, in January 2011, on one of the following courses as part of their degrees: Management Accounting (MA); Computer Systems Management (CSM); Business Administration and Organization of Production (BAOP); or Economics and Industrial Organization (EIO). According to data from the Office for Analysis and Planning at the University of La Laguna, the total number of students officially registered on these courses at that time was 217 .

For the data collection the professors of these courses uploaded the questionnaire onto the corresponding Virtual Classroom at the end of the first four-month term of the academic year 2010-2011, after the students took their exams but before they learned their grades in order to encourage greater homogeneity and objectivity in the responses.

The professors received 126 validly completed questionnaires, which represents a response rate of 63\%. Table 2 shows the response rate in each course.

The information collected was codified and stored in a database for subsequent treatment (preliminary analysis of data quality and replacement of absent data by the mean of the series using the statistics program SPSS 19.0). The statistical analysis of the data followed, and the following subsections look at the results.

The SPSS 19.0 program was used to analyze the validity and reliability of the measurement scale used to measure the quality of the project to test the innovative methodology in entrepreneurship education. After confirming the normality and linearity, the Cronbach alpha coefficient was calculated to evaluate the internal consistency of the indicators of each latent variable. The results show that each set of observed variables is representative of its corresponding factor, since values close to or exceeding 0.6 are considered acceptable in exploratory analyses (Hair et al., 1999). Thus for Implementation of project and Degree of satisfaction this statistic is lower than 0.6 but remains acceptable because it exceeds the minimum of 0.5 (0.504 and 0.545 , respectively). For the other two dimensions-Results of learning and Fundamental elements of innovative methodology - the statistic gives higher values ( 0.654 and 0.756 , respec- 


\section{F. J. GARCÍA-RODRÍGUEZ ET AL.}

Table 1.

Items in Quality of project to test innovative teaching methodology.

Implementation of project

I1. The professor informed us at the beginning of the course how the project was going to proceed (objectives, content, methodology, evaluation, duration...)

I2. The initially established deadlines for the project were met

I3. The professor resolved any doubts we had during the project clearly and quickly

\section{Results of learning}

I4. Participating in the project has helped improve my understanding of the contents of this course

I5. After participating in this project I now understand the business environment better

I6. Participating in this project has allowed me to apply what I have learnt in this course to the business reality, orienting my knowledge to the solution of real problems

I7. After participating in this project I am more likely to start a business at some time in the future

I8. This project has enabled cooperation with students from other degrees, which has given me a new perspective in the solving of real problems

\section{Fundamental elements of innovative methodology}

19. The structure of the project was clear, logical and organized

I10. The professor gave a clear explanation of the concepts involved in the implementation of the project

I11. Working on the project has provided us with motivation and interest in the course

I12. The teamwork with classmates from my degree was fruitful and stimulating

I13. The teamwork with classmates from other degrees was fruitful and stimulating

I14. The material recommended (bibliography, documentation, transparencies, etc.) helped us carry out the work and was easily accessible

I15. The virtual classroom and the information and communication technologies were adequate and useful in doing the work

I16. I think the evaluation criteria and the weight of the project in the total grade for the course are about right

\section{Degree of satisfaction}

I17. In general, I am satisfied with how the practical work went

I18. In general, I am satisfied with the professor's support of the practical work

I19. I think I learnt a lot from doing this work and it will be useful for my education

I20. Doing this work meant that this course required more effort than the other courses

Table 2.

Composition of population and sample size.

\begin{tabular}{ccccc}
\hline COURSE & Degree & No. students registered & No. questionnaires & Response rate \\
\hline Management Accounting (MA) & Business Management & 104 & 48 & $46 \%$ \\
Computer Systems Management (CSM) & Computer Engineering & 30 & 15 & $50 \%$ \\
$\begin{array}{c}\text { Business Administration and Organization of } \\
\text { Production (BAOP) }\end{array}$ & Industrial Engineering & 62 & 46 & $74 \%$ \\
Economics and Industrial Organization (EIO) & Chemical Engineering & 21 & 17 & $81 \%$ \\
Total & & $\mathbf{2 1 7}$ & $\mathbf{1 2 6}$ & $\mathbf{6 3 \%}$ \\
\hline
\end{tabular}

tively). The Cronbach alpha for the whole scale is 0.858 , which means that the questionnaire is reliable as a whole. Finally, with regard to the discriminant validity, for a 95\% confidence interval the correlation between each pair of latent variables does not contain the value 1 . The variables are not perfectly correlated, so they each represent a distinct concept.

\section{Results}

The authors now look at the main results. They first analyze the four dimensions defining the quality of the teaching innovation in entrepreneurship, using the questionnaire described and validated previously. They then evaluate the predisposition to engage in entrepreneurship among the students participating in the project in comparison to the population in general according to data from GEM.

\section{Implementation of Project}

The results in Table $\mathbf{3}$ show that the students thought highly about the aspects relating to the implementation of the project. 


\section{F. J. GARCÍA-RODRÍGUEZ ET AL.}

More than $90 \%$ select the most favorable responses (agree or strongly agree) in the case of items I1 (The professor informed us at the beginning of the course how the project was going to proceed) and I3 (The professor resolved any doubts we had during the project clearly and quickly). The students are less positive about item I2 (The initially established deadlines for the project were met): $27 \%$ opt for the least favorable responses (strongly disagree or disagree). Looking at the results by degree, these students are studying the courses MA and BAOP, their work teams have the most members and they provide the most questionnaires (see Table 2).

With regard to this latter item, the authors should note that the limitations due to the time available and the number of participating students were an enormous obstacle to the organization of the work groups, so that in some cases (MA and BAOP) the professors had to establish big groups (average of 16 students per group). This led to some loss of control on the part of the professors and a reduced capacity of interaction or feedback between professors and students and between students.

\section{Results of Learning}

Table 4 shows the proportions of students selecting each of the five options in the questionnaire from strongly disagree to strongly agree. In general, the students participating in the project have a very positive opinion about the results of their learning. This is particularly the case in the aspects to do with understanding of contents (I4), knowledge of the business environment (I5), and application of learning to solving real business problems (I6). At the same time, with regard to the promotion of entrepreneurial spirit (I7), $44 \%$ of the students manifest a clear predisposition toward entrepreneurship in the future, with $28.8 \%$ and $15.2 \%$ responding agree and strongly agree, respectively.
In contrast, it is striking to see that $23.8 \%$ of the students have a very unfavorable opinion about the interdisciplinary nature of the project (item I8: This project has enabled cooperation with students from other degrees, which has given me a new perspective in the solving of real problems). The large group sizes and the separation between education centers (the students participating in the project came from two different university campuses) put enormous difficulties in the way of the normal development of the work. The authors consider that they are the main reasons for this result.

\section{Fundamental Elements of Innovative Methodology}

This dimension consists of aspects to do with: the organization and methodology of the work; the team work; the teaching materials; the use of ICT; and the evaluation of the learning. In general, the respondents have a very favorable opinion about the elements of the innovative methodology. Table 5 shows that nearly $80 \%$ respond agree or strongly agree in all but two cases. The respondents have a slightly less favorable opinion about item I14 (The material recommended helped us carry out the work and was easily accessible).

In addition, $32.8 \%$ of the students have a very unfavorable opinion about item I13 (The teamwork with classmates from other degrees was fruitful and stimulating). Looking at this result, a connection exists with that of item I8 (This project has enabled cooperation with students from other degrees, which has given me a new perspective in the solving of real problems). These two results point to potential improvements to the project in future years.

\section{Degree of Satisfaction}

The students participating in the project are very satisfied with the development of the business plan (I17), the support of

Table 3.

Evaluation of implementation of project (\%).

\begin{tabular}{|c|c|c|c|c|c|}
\hline Implementation of project & $\begin{array}{l}\text { Strongly } \\
\text { disagree }\end{array}$ & Disagree & $\begin{array}{l}\text { Neither disagree } \\
\text { nor agree }\end{array}$ & Agree & $\begin{array}{l}\text { Strongly } \\
\text { agree }\end{array}$ \\
\hline $\begin{array}{l}\text { I1. The professor informed us at the beginning of the course how the project was } \\
\text { going to proceed (objectives, content, methodology, evaluation, duration...) }\end{array}$ & - & 2.4 & 2.4 & 50.4 & 44.8 \\
\hline I2. The initially established deadlines for the project were met & 5.6 & 21.8 & 12.1 & 41.9 & 18.5 \\
\hline I3. The professor resolved any doubts we had during the project clearly and quickly & - & 3.2 & 6.4 & 40.8 & 49.6 \\
\hline
\end{tabular}

Table 4.

Evaluation of results of learning (\%).

\begin{tabular}{|c|c|c|c|c|c|}
\hline Results of learning & Strongly disagree & Disagree & $\begin{array}{l}\text { Neither disagree } \\
\text { nor agree }\end{array}$ & Agree & $\begin{array}{l}\text { Strongly } \\
\text { agree }\end{array}$ \\
\hline $\begin{array}{l}\text { I4. Participating in the project has helped improve my understanding of the } \\
\text { contents of this course }\end{array}$ & 0.8 & 3.2 & 9.6 & 55.2 & 31.2 \\
\hline $\begin{array}{l}\text { I5. After participating in this project I now understand the business } \\
\text { environment better }\end{array}$ & 0.8 & 3.2 & 12.0 & 56.0 & 28.0 \\
\hline $\begin{array}{l}\text { I6. Participating in this project has allowed me to apply what I have learnt in this } \\
\text { course to the business reality, orienting my knowledge to the solution of real } \\
\text { problems }\end{array}$ & - & 4.8 & 20.0 & 51.2 & 24.0 \\
\hline $\begin{array}{l}\text { I7. After participating in this project I am more likely to start a business at some } \\
\text { time in the future }\end{array}$ & 5.6 & 12.8 & 37.6 & 28.8 & 15.2 \\
\hline $\begin{array}{l}\text { I8. This project has enabled cooperation with students from other degrees, which } \\
\text { has given me a new perspective in the solving of real problems }\end{array}$ & 23.8 & 12.7 & 24.6 & 30.2 & 8.7 \\
\hline
\end{tabular}


Table 5.

Evaluation of Fundamental elements of innovative methodology (\%).

\begin{tabular}{|c|c|c|c|c|c|}
\hline Fundamental elements of innovative methodology & Strongly disagree & Disagree & $\begin{array}{l}\text { Neither disagree } \\
\text { nor agree }\end{array}$ & Agree & $\begin{array}{l}\text { Strongly } \\
\text { agree }\end{array}$ \\
\hline I9. The structure of the project was clear, logical and organized & 0.8 & 6.4 & 14.4 & 61.6 & 16.8 \\
\hline $\begin{array}{l}\text { I10. The professor gave a clear explanation of the concepts involved in the } \\
\text { development of the project }\end{array}$ & - & 6.5 & 13 & 56.9 & 23.6 \\
\hline $\begin{array}{l}\text { I11. Working on the project has provided us with motivation and interest in the } \\
\text { course }\end{array}$ & 1.6 & 2.5 & 13.1 & 64.8 & 18 \\
\hline I12. The teamwork with classmates from my degree was fruitful and stimulating & 1.6 & 5.6 & 12.9 & 44.4 & 35.5 \\
\hline $\begin{array}{l}\text { I13. The teamwork with classmates from other degrees was fruitful and } \\
\text { stimulating }\end{array}$ & 32.8 & 19.7 & 30.3 & 13.9 & 3.3 \\
\hline $\begin{array}{l}\text { I14. The material recommended (bibliography, documentation, transparencies, } \\
\text { etc.) helped us carry out the work and was easily accessible }\end{array}$ & 1.6 & 8.0 & 24.0 & 52.0 & 14.4 \\
\hline $\begin{array}{l}\text { I15. The virtual classroom and the information and communication technologies } \\
\text { were adequate and useful in doing the work }\end{array}$ & 0.8 & 2.4 & 9.6 & 52.8 & 34.4 \\
\hline $\begin{array}{l}\text { I16. I think the evaluation criteria and the weight of the project in the total grade } \\
\text { for the course are about right }\end{array}$ & 1.6 & 8.9 & 12.2 & 53.7 & 23.6 \\
\hline
\end{tabular}

the professor (I18), and the utility of the knowledge acquired (I19). This in spite of the fact that the majority consider that carrying out the project meant that the course demanded more effort then the rest of the courses (I20). Table 6 shows the main results for the degree of satisfaction.

\section{Aspect to Improve}

The questionnaire included an open question asking the participants for their opinion about how the project had gone and for their suggestions for improvement. A large majority express a very positive opinion about their participation in this project, mainly because it has provided them with a new perspective on the course, and brought the academic content closer to the professional reality. But at the same time they mention a number of difficulties and offer some suggestions for improvement:

1) Interaction between group members. The students stress that the excessive group size made the teamwork more difficult; some students did not get particularly involved because they did not consider the course to be fundamental; different learning rhythms in the four courses involved; incompatibility of class times between group members based in centers on different university campuses.

2) Duration of project. The students argue that they had barely enough time to do the work considering the objectives.

3) Weight of project. Students stress the need to increase the weight of the project in the total grade for the course, given its importance.

\section{Participants’ Attitudes toward Entrepreneurship after Finishing Project}

The authors evaluated the students' attitude and pre-disposition toward entrepreneurship and compared the results with data from the Annual Report of the GEM on entrepreneurial activity in Spain in 2009 (De la Vega et al., 2009). They considered two fundamental dimensions: the entrepreneurial activity and dynamic; and the motivation and capacity to engage in entrepreneurial activity.

According to De la Vega et al. (2009), 5.7\% of the Spanish adult population is considering starting a new business in the next three years, compared to $24 \%$ of the university students participating in this project. In addition, 5.1\% of the Spanish active population have started or tried to start a new business in the past 3.5 years, compared to $9 \%$ of the students in this study. Consequently, the intention and the attitude toward entrepreneurship is significantly superior among the university students participating in this study than in the active Spanish population in general.

On the other hand, $51 \%$ of the Spanish adult population say that they have the knowledge, skills and experience necessary to start a new business venture, compared to $50 \%$ of the students. But almost $17 \%$ of the general population perceive opportunities to start a business, compared to only $6 \%$ of the students.

\section{Conclusion, Limitations and Implications}

The current work has described the methodology and the main results of a project to test an innovative methodology for teaching entrepreneurship. The methodology involves the elaboration of business plans by multidisciplinary teams of students studying for scientific-technical or business management degrees at the University of La Laguna (Spain).

The authors can conclude from the results that the interdisciplinary elaboration of business plans is an excellent pedagogical tool in economics/business and scientific-technical degrees in response to some of the challenges higher education is currently facing in the international context in general and in Europe in particular. The authors would stress the potential of such projects to promote entrepreneurial spirit among students-a key element in the University's progress toward fulfilling its "third mission" on top of its traditional teaching and research roles. In this respect, after participating in the project the students manifest a greater long-term intention to start a business than the general Spanish population.

At the same time, the methodology described seems to be offering the students learning closer to the real world, a closer contact with the business reality, and a greater involvement in the solution of real problems.

In order to exploit the potential of this interdisciplinary approach it is essential to give the students the most individualized attention possible. In this respect, the size of each group 
Table 6.

Evaluation of degree of satisfaction (\%).

\begin{tabular}{|c|c|c|c|c|c|}
\hline Degree of satisfaction & Strongly disagree & Disagree & $\begin{array}{l}\text { Neither disagree } \\
\text { nor agree }\end{array}$ & Agree & $\begin{array}{c}\text { Strongly } \\
\text { agree }\end{array}$ \\
\hline I17. In general, I am satisfied with how the practical work went & - & 3.2 & 11.2 & 61.6 & 24 \\
\hline I18. In general, I am satisfied with the professor's support of the practical work & 0.8 & 2.4 & 4 & 56.5 & 36.3 \\
\hline $\begin{array}{l}\text { I19. I think I learnt a lot from doing this work and it will be useful for my } \\
\text { education }\end{array}$ & 1.7 & 1.7 & 14.9 & 62.0 & 19.8 \\
\hline $\begin{array}{l}\text { I20. Doing this work meant that this course required more effort than the other } \\
\text { courses }\end{array}$ & 2.4 & 4.8 & 30.4 & 33.6 & 28.8 \\
\hline
\end{tabular}

and the number of groups that the professors must coordinate are key variables, since the students' motivation and their perception of the quality of the process decline considerably as group size or the number of groups grows. The process of forming the interdisciplinary work teams must be done carefully, and the students of the different degrees must be offered efficient tools, spaces and methods of contact, coordination and communication. Otherwise much of the potential of the interdisciplinary work process may be lost.

It would be very interesting to deepen the analysis of the impacts among the students of entrepreneurship teaching methodologies via the creation of interdisciplinary teams, like the one described in the current work, and compare them with more classical teaching methodologies.

It would also be useful to isolate the specific effect on the students of participating in the project. One limitation of the current work is that it cannot determine the consequences in terms of entrepreneurial motivation that are attributable exclusively to the project. The differences between the participating students and the general population in terms of entrepreneurial motivation could in part be due to the socio-economic context or sociodemographic characteristics such as age or labor situation. Thus it would be interesting to carry out a longitudinal analysis to compare the situation before and after the students' participation in the project. This research project has been focused in students coming from specific universitary courses. Therefore the methodology should be tested in the future with students coming from other pedagogical contexts in order to test the universal validation of the results.

\section{REFERENCES}

Athayde, R. (2009). Measuring enterprise potential in young people. Entrepreneurship: Theory \& Practice, 33, 481-500. doi:10.1111/j.1540-6520.2009.00300.x

Audretsch, D. B. (2002). Entrepreneurship: A survey of the literature for the European Commission, Enterprise Directorate General. http://europa.eu.int/comm/enterprise/library/enterprise-papers/pdf/ent erprise_paper_14_2003.pdf

Béchard, J. P., \& Grégoire, D. (2005). Entrepreneurship education research revisited: The case of higher education. Academy of Management Learning \& Education, 4, 22-43.

doi:10.5465/AMLE.2005.16132536
Commission of the European Communities (2003). Green paper: Entrepreneurship in Europe. Brussels: European Commission. http://www.smallbusiness.outreach.ou.edu/teleconference/green_pap er_final_en.pdf

Commission of the European Communities (2008). Survey of entrepreneurship in higher education. Brussels: European Commission. http://ec.europa.eu/enterprise/policies/sme/files/support_measures/tra ining_education/highedsurvey_en.pdf

Fayolle, A. (2007). Handbook of research in entrepreneurship education: A general perspective. Cheltenham: Edward Elgar Publishing, Ltd.

Fiet, J. O. (2001). The pedagogical side of entrepreneurship theory. Journal of Business Venturing, 16, 101-117. doi:10.1016/S0883-9026(99)00042-7

Honig, B. (2004). Entrepreneurship education: Toward a model of contingency-based business planning. Academy of Management Learning \& Education, 3, 258-273. doi:10.5465/AMLE.2004.14242112

Katz, J. A. (2008). Fully mature but not fully legitimate: A different perspective on the state of entrepreneurship education. Journal of Small Business Management, 46, 550-566. doi:10.1111/j.1540-627X.2008.00256.X

Kuratko, D. F. (2005). The emergence of entrepreneurship education: Development, trends, and challenges. Entrepreneurship Theory and Practice, 29, 577-598. doi:10.1111/j.1540-6520.2005.00099.x

Mauri, T., Coll, C., \& Onrubia, J. (2007). The evaluation of the quality of university innovation processes. A constructivist perspective. Red U. Revista De Docencia Universitaria, 1, 5-17.

Neck, H. M., \& Greene, P. G. (2011). Entrepreneurship education: Known worlds and new frontiers. Journal of Small Business Management, 49, 55-70. doi:10.1111/j.1540-627X.2010.00314.X

O’Shea, R. P., Allen, T. J., Morse, K. P., O'Gorman, C., \& Roche, F. (2007). Delineating the anatomy of an entrepreneurial university: The Massachusetts institute of technology experience. R\&D Management, 37, 1-16.

Peterman, N. E., \& Kennedy, J. (2003). Enterprise education: Influencing students' perceptions of entrepreneurship. Entrepreneurship: Theory \& Practice, 28, 129-144. doi:10.1046/j.1540-6520.2003.00035.x

World Economic Forum (WEF) (2009). Educating the next wave of entrepreneur. Geneva: WEF.

Zeithaml, C. P., \& Rice, G. (1987). Entrepreneurship/small business education in American universities. Journal of Small Business Management, 25, 44-50.

Zhou, C., \& Luo, L. (2012). Group creativity in learning context: Understanding in a social-cultural framework and methodology. Creative Education, 3, 392-399. 